\title{
Creating Networks from the Past into the Future: Historical Heritage and Civil Society
}

\author{
Paloma González Marcén ${ }^{1}$, Xavier Roda Gilabert ${ }^{2}$
}

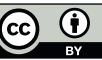

\begin{abstract}
Taking inspiration from the Convention of the Council of Europe on the value of cultural heritage for society, signed in 2005 in Faro (Portugal), in the 8th Seminar of Archaeology and Education met during three days professionals from the field of historical and archaeological research, public administration, cultural management, education and citizens associations taht had been or were carrying out projects of civil society participation in the management and valuation heritage with the aim of facilitating a sharing of experiences and reflections of the different parties involved in projects, both from the point of view of its scientific content, and their career goals, social, educational and procedures employed.
\end{abstract}

Keywords: historical heritage; civil society; Faro convention; heritage management.

Resum. Creant xarxes del passat al futur: patrimoni històric i societat civil

Prenent com a inspiració la convenció del Consell d'Europa sobre el valor del patrimoni cultural per a la societat, signada el 2005 a Faro (Portugal), el 8è Seminari d'Arqueologia i Ensenyament va reunir, al llarg de tres dies, professionals procedents del camp de la investigació històrica i arqueològica, l'administració pública, la gestió cultural, l'associacionisme ciutadà i la didàctica que haguessin portat o estiguessin duent a terme projectes de participació de la societat civil en la gestió i valoració patrimonial amb la voluntat de facilitar la posada en comú de les experiències i reflexions de les diferents parts implicades en els projectes, tant des del punt de vista del seu contingut científic com dels seus objectius professionals, socials i educatius i dels procediments emprats.

Paraules clau: patrimoni històric; societat civil; convenció de Faro; gestió del patrimoni.

Resumen. Creando redes del pasado al futuro: patrimonio histórico y sociedad civil

Tomando como inspiración la convención del Consejo de Europa sobre el valor del patrimonio cultural para la sociedad, firmada en 2005 en Faro (Portugal), el 8a Seminario de Arqueología y Enseñanza reunió, a lo largo de tres días, a profesionales procedentes del campo de la investigación histórica y arqueológica, la administración pública, la gestión cultural, el asociacionismo

1. CEPAP-Universitat Autònoma de Barcelona. Facultat de Filosofia i Lletres. 08193 Bellaterra. paloma.gonzalez@uab.cat

2. CEPAP-Universitat Autònoma de Barcelona. Facultat de Filosofia i Lletres. 08193 Bellaterra. javier.roda@uab.cat 
ciudadano y la didáctica que hubieran llevado o estuvieran llevando a cabo proyectos de participación de la sociedad civil en la gestión y valoración patrimonial con la voluntad de facilitar la puesta en común de las experiencias y reflexiones de las diferentes partes implicadas en los proyectos, tanto desde el punto de vista de su contenido científico como de sus objetivos profesionales, sociales y educativos y de los procedimientos empleados.

Palabras clave: patrimonio histórico; sociedad civil; convención de Faro; gestión del patrimonio.

GonzÁlez Marcén, Paloma; Roda Gilabert, Xavier. «Creating Networks from the Past into the Future: Historical Heritage and Civil Society». Treballs d'Arqueologia, 2012, núm. 18, p. 3-7.

If we could revise here the most stimulating academic and instrumental contributions from the last two decades regarding the social value of cultural heritage, and more specifically of historical heritage, we would confront the apparent paradox that they deal neither about heritage nor about society, but about the multiplicity of links that are built or rebuilt between them. This fundamental shift in the theory and practice of heritage management is the ground on which the very notion of public dimension of heritage is founded.

Multiplicity and diversity are heuristic connected concepts which crystallized in the Council of Europe document, Framework Convention on the Value of Cultural Heritage for Society signed in Faro (Portugal) in 2005 (Council of Europe 2009). This document draws attention to three innovative values attached to cultural heritage: diversity, cultural rights and peaceful and democratic coexistence. Cultural heritage is, in this sense, no longer simply an inherited richness to appreciate and enjoy, but rather is an expression of rights that must be acknowledged in any real democratic society. In this period of economic difficulties, increasing cultural diversity and a multiplicity of communication networks, the challenge posed by the Faro Convention is huge and, therefore, has to be approached in an analytical way, by means of differentiated, but intertwined, realms of research and action.

In current proposals about heritage links with the public, the emotional relationship and reaction that specific heritage elements or assets arouse in visitors have acquired a fundamental importance. In this context, there are two basic concepts which guide heritage theorizing and display: identity and sense of place. In both issues, the starting point is the idea that a determined material setting asserts people belonging to a specific community (cultural, ethnical, religious, political, etc.), providing a sense of harmonic relationship with that specific place. It could be proposed that, regarding identity there is a group affiliation and according to sense of place, an environmental affiliation, The importance of these concepts lies not only in a more accurate characterization of the relationships between public and historical heritage, but also permits to explain and consequently to manage, its significance value given. 
This instrumental capacity of identity and sense of place concepts has been the main reflection subjects in the research of the public dimension of cultural heritage, as in programmes and activities implementation specifically directed to promote significant heritage dissemination experiences. Therefore, recently has been exhibit the interweaving of heritage identity value with the implementation and reproduction of determined political and ideological view, as well as with the vindication and recognition of disenfranchised groups and communities (Meskell 2002). While in America and Australia these initiatives are mainly focused on the recovery and valorisation of indigenous cultural heritage, in Europe traditional national identities have begun to tackle the challenge of incorporating in their definition other sensibilities mainly expressed in two fields. On one hand, it is being questioned the problematic character of an homogeneous historical identity, recovering and showing the cultural heritage of communities with roots during the past in different states, and on the other hand, with a view toward the future, conforming a definition and interpretation of the historical heritage based in the cultural experiences of new Europeans citizens (Holtorf 2009).

Hence, it is expected not only to attend to the request of the diverse public sector to feel represented (in other words, identified) with the proper historical heritage, but also to promote the sense of belonging of the diversity of cultural collectives within current European population to their living places and thus, to promote cultural cohesion according to shared models, This complex ambition, due to the difficult equilibrium between cohesion and diversity right, define one of the most important duties to be conducted from theoretic and practicum fields of the public dimension of European cultural heritage.

Moreover, the collision of diverse identity and significance values has generated and generates conflict scene within the access and public presentation of historical heritage (Chilton \& Silberman 2010). The imposition of a majority view about social or cultural minorities or the unilateral interpretation about historical conflicts, specifically those of recent perio$\mathrm{d}$, require clear theoretical positions and a systematic arbitration among the diverse sensibilities. This difficulty is exhibit primarily in contemporaneous historical heritage, provided that associated experiences to these elements live on in many people memory which were involved directly or indirectly on them (Harrison \& Schofield 2010).

A specific kind of actions oriented to promote citizen's involvement in heritage preservation and interpretation have begun to conform a structured area both of public engaging with historical heritage and of academic research. This kind of activities, labeled with the term of community projects, is the result of different social trends and cultural traditions (Waterton \& Smith 2010). On one hand, in the Anglo-Saxon world, heritage, and especially historical heritage, conforms a long lasting field of activities for voluntary groups and amateur historians and archaeologists with a particularly strong relation and often a mystified idea of the past. On the other hand, the social demands of a renewed model of citizen involvement in everyday politics has fostered since the late 80 's the so called participatory practices focused on decision-making about local affairs. Due mostly to these two main 
factors, community programmes are permeating heritage management in many European countries, although with very different characteristics and a markedly uneven distribution.

Perhaps is within this area related to the local people's involvement in the stewardship and interpretation of historical heritage, where the intra-European diversity shows to be more acute between national cultural traditions. So, for example, most British community projects are activated by identity or cultural motivation, while Spanish ones are mainly political oriented; British projects tend to have a structured methodology, while Spanish lacking of formulated procedures (Gonzalez-Ruibal 2007). However, participatory actions are called to characterize not only the future of historical heritage management, but the future of heritage itself, since the citizen's demands to incorporate them into heritage research and outreach is going to become a growing social vindication, as is happening in other realms of governance.

The participatory approach of community projects is implied by Fowler (2003), according to the management of European cultural landscapes. He states they should be governed by the principle of sustainability to avoid the fossilization of these areas o cities, allowing them to benefit from economic development. Following Fowler, stress should be given not only to heritage conservation, but also to the cultural and the economical needs of the local population as an essential component of the sustainability concept.

In parallele, in the last 20 years, heritage education has gained prominence both as a theoretical and practical/methodological issue in the European cultural and educational policies of an increa- sing number of countries and, especially, of international cultural and professional institutions. This awareness among heritage professionals arose as a new conception of heritage policies aiming, as primary objective, to ensure heritage conservation by means of an active involvement of the public. As a consequence, a first set of educational programmes were launched to make visible heritage at a school level, so that European children and teenagers were made aware of their existence and about their historical and/or cultural value. In a second stage, new inputs brought in by the professionals involved in heritage education (educators, curators, historians, archaeologists, etc.) began to refine the characterization of heritage education with respect to methodological issues. This more detailed concept was finally fixed in the 1998 Recommendation of the Committee of Ministers of the Council of Europe in which it was stated that 'Heritage education means a teaching approach based on cultural heritage, incorporating active educational methods, cross-curricular approaches, a partnership between education and culture and employing the widest variety of modes of communication and expression.'

This methodological emphasis on heritage education has come from the expansion in many European countries of heritage-oriented projects, mostly based on outdoor active, hands-on activities and on a direct contact or experience of those heritage elements included in the school programmes (Henson et al. 2004). In contrast to the traditional concept of history teaching, heritage related activities were and are experienced by pupils and students as enjoyable and from the point of view of the teachers, they are considered useful as pedagogical tools. In this line, the recog- 
nition of the role that education can play assets as a tool to stimulate social integration and transmission of values (Copeland 2006).

In sum, historical heritage is an issue about meaning and new conceptualizations are needed in order to situate in the forefront of discussion the kind of multilayered heritages that have been created in by means of management policies and par- ticipatory and educational experiences. As a final reflection we may point out that although heritage is often linked exclusively with past and conservation, in fact the collective meaning acquired by heritage elements has much more to do with expectations and the construction of futures. Perhaps this is the most valuable idea to retain, in the context of the future of the relationship linking historical heritage.

\section{References}

Council of Europe. 2009. Heritage and beyond. Strasbourg, Council of Europe Publishing. Chilton, E.; Silberman, N. 2010. Heritage in Conflict and Consensus: towards an international agenda for the twenty first century. Museum International 62(1 2): 6-8.

Copeland, T. 2006. European democratic citizenship, heritage education and identity. Strasbourg: Council of Europe

FOWLER, P. 2003. World Heritage Cultural Landscapes 1992-2002. World Heritage Papers 6. Paris: UNESCO World Heritage Centre.

GonZÁleZ-Ruibal, A. 2007. Making things public: archaeologies of the Spanish Civil War. Public Archaeology 6(4): 203-26.

HARRISON, R.; SCHOFIELD, J. 2010. After modernity: Archaeological approaches to the contemporary past. Oxford: Oxford University Press.

Henson, D., Stone, P.G.; Corbishley, M. (eds.) 2004. Education and the Historic Environment. London: Routledge

Holtorf, C. 2009. A European perspective on indigenous and immigrant archaeologies. World Archaeology 41(4): 672-81.

MESKELL, L. 2002. The intersections of identity and politics in archaeology. Annual Review of Anthropology 31: 279-301.

WATERTON, E.; SMith, L. 2010. The recognition and misrecognition of community heritage. International Journal of Heritage Studies 16(1-2): 4-15. 